\title{
The Political Aspect of Misogynies in Late Qing Dynasty Crime Fiction
}

\author{
Lavinia Benedetti \\ University of Catania, Catania, Italy
}

\begin{abstract}
In most Chinese traditional court-case narrative, women often serve as negative social actors, and may even be the alleged cause of the degeneration of men's morality as the result of their seductiveness. In the late Qing Dynasty novel Digong'an, centred on the upright official Digong, there is strong evidence of misogyny by the author. Two female characters stand out from the story: one kills her husband with the help of her lover, who is partially justified by the latter being under the woman's negative influence; and the other is Empress Wu, to whom the moral downfall of the Tang Dynasty is attributed. Both women are subject to insult and threat throughout the novel. The author's attitude substantially relies on the sexist rhetoric prevalent in the Confucian idea of an ordered society, which usually took a negative outlook towards women partaking in public life. But for the latter we should also take in account that at the end of the Qing Dynasty a woman was, in reality, ruling the empire "from behind the curtain”. Therefore, the purpose of this paper is to deconstruct the author's misogyny, in order to shed a light on his criticism and connect it with a somewhat more political discourse.
\end{abstract}

Keywords: Chinese courtcase novel, Digong'an, political criticism, Empress Cixi

\section{Introduction}

Crime and punishment are much appreciated themes in Chinese narrative production since its very beginning. Stories of criminal cases brought to trial, of murders, thefts, deceptions, disputes; tales of honest and upright officials performing a variety of legal duties or of corrupt officials who abuse their power, etc. are just some of the topics related to this type of narrative that exists in various forms and genres, be it for works in classical language or in the vernacular.

An ancestor of crime stories may be found in the ancient tradition of Chinese myths and legends, while a marked taste for stories related to criminal cases begins to stand out in literati's works of narrative as early as the Tang period. ${ }^{1}$ As far as we know, in the Song period (960-1279) a specific genre devoted to court-case stories called 说公案 (shuo gong'an, speaking about court-case stories) appeared among the subjects of storytellers' oral tales, and among the earliest form of written novels in the vernacular, called 话本 (huaben). ${ }^{2}$ The gong'an as a subject of vernacular stories is mentioned for the first time by the literatus Nai deweng (耐得 翁, dates unknown) in his 都城纪胜 (Ducheng Jisheng, Notes on the Chief Sights of the Capital), and by Luo

Lavinia Benedetti, Researcher in Chinese Language and Literature, Faculty of Foreign Languages and Literatures (Struttura didattica Speciale, Ragusa), University of Catania.

${ }^{1}$ HUANG Yanbo (2000), 公案小说史话 (History of Crime Fiction), p. 3.

${ }^{2}$ Unlike earlier works of narrative, 话本 used a written language that reflected the language spoken at the time, which automatically excluded it from the literary canon, which instead used a language based upon the Classics 
Ye (罗烨, dates unknown) in its 醉翁谈录 (Zuiweng tanlu, Commented Record of an Old Drunk), both works available in early Yuan editions. ${ }^{3}$ In Luo's work are collected also seventeen titles of short stories categorised as gong'an, although he does not specify what the content of these stories was. These stories represent the first examples of 公案小说 (gong'an xiaoshuo, court-case fiction, or crime fiction).

The term 公案 (gong'an) was originally used to refer both to the court case and to the bench in the magistrate's office, where his ink stone for rubbing black and red ink and his brushes, as well as the office seals, were positioned. ${ }^{4}$ The magistrate, in fact, always appears in court-case literature, and at least since the Ming period (1368-1644), there is a literary genre where he is the protagonist. In the narrative, the magistrate investigates cases and issues the judgment. In a similar way, the administration of justice was one of the most important duties of a county official in China: representing in loco the imperial majesty, he was entrusted with all aspects of local affairs in the area and took centre stage in performing a variety of crucial tasks, including administering justice. ${ }^{5}$ Concerning the term 小说 (xiaoshuo), throughout Chinese history, historians have used it with different connotations, but we can easily understand it as something referring to works of fiction, which primary purpose, at least since the Tang Dynasty (618-907), was to entertain readers. ${ }^{6}$

It was thanks to Song and Yuan storytellers that the 公案小说 (gong’an xiaoshuo) went on codifying itself structurally and thematically, introducing some of the most cherished themes of Chinese vernacular fiction, such as stories of injustice (冤枉, yuanwang), and anticipating some of the stereotypical characters, such as the "upright magistrate” (清官, qingguan). Characters, plots, and subject matters of the stories from the Song period are proposed also in Yuan drama (公案戏, gong’an xi), in the imitative vernacular narrative of Ming scholars (拟话本, nihuaben), in the collections of short stories of the Ming period (短篇公案小说, duanpian gong’an xiaoshuo) and, finally, in the chaptered court-case novels of the Qing period (白话章回小说, baihua zhanghui xiaoshuo). This kind of narrative is usually studied for its social role as a form of entertainment. Yet, the subject matters of vernacular crime literature itself, though excluded from the canon of edifying literature, have been lastingly and all along connected with a somewhat more conceptual and symbolic moral discourse.

\section{Vernacular Crime Fiction During the Qing Period}

We can divide the production of vernacular crime fiction during the Qing Dynasty (1644-1911) into three genres.

The first one is what I called "crime stories as exempla” that appeared in the early Qing period. At the

\footnotetext{
${ }^{3}$ MIAO Huai-ming (2005), 中国古代公案小说史论 (History of Ancient Chinese Detective Novels), pp. 27-39.

${ }^{4}$ LIU Wei-min (2011), 侦探小说评析 (Discussion on detective novel), p. 1.

${ }^{5}$ People could report any kind of crime (homicide, robbery, theft, adultery, kidnapping) to a local official at any time by just beating the gong in front of the yamen to signal their desire for a hearing. In cases of homicide, the magistrate and his staff (many hundreds in a typical district and more than a thousand people in a larger district, including coroners, jailers, policemen, guards, executioners, grooms, messengers, scribes, watchmen, and others) were entrusted with collecting all relevant information concerning the crime, from the physical evidence of the facts, to the witnesses' declarations, up until the arrest of the principle suspects, but also of all those capable of providing any information that may lead to the resolution of the case. Once the evidence had been collected and examined, the magistrate proceeded with the questioning. The law imposed a series of deadlines on the magistrate: the time by which he was required to resolve the case, obtain a confession, and submit a detailed report to his superior. Delay in completing such report was punishable, and sometimes the terms within which he had to carry out these operations were very tight, even unrealistic. A criminal confession was always required, and the magistrate was legitimized to use of physical torture on suspects and witnesses to obtain it, using a variety of canes, presses, and chains to prompt confessions. For further information, see Ch’ü (1988), Local Government in China under the Ch'ing, pp. 116-129; and Brook, Bourgon, Blue (2008), Death by a Thousand Cuts, p. 43.

6 See LU Hsun (1976), A Brief History of Chinese Fiction, pp. 1-10.
} 
beginning of the Qing era, the plan for the consolidation of power by the first Manchu sovereigns included a heavy-handed ideological control over literature and moved to implement a repressive cultural policy, especially over the vernacular narrative. ${ }^{7}$ As a consequence vernacular narrative lost its characteristic of lively expression, and more than often literati used the vernacular as an instrument to reinforce the importance of traditional values. The short crime stories we found in the works by literati during this period were written in order to instruct the reader and to condemn behaviours contrary to traditional ethical principles, lavishing on the reader all kind of advice and admonitions. Some of them may be even found in collections, meant to move away from the narrative tradition and disclose their objective to provide a background social model intended to be imitated by the components of society. ${ }^{8}$

The second genre appeared around the middle of the nineteenth century. In this period, with the relaxation of government policy, the market of oral literature developed, especially in Beijing and northern areas. Moreover, the introduction of Western innovations in publishing technology helped knock down prices and improve the efficiency of the press, fostering a renaissance for vernacular written literature. In this period new genres of crime fiction came into existence, such as the chaptered novels of adventure and detection (公案侠义 小说, gong'an xiayi xiaoshuo), which were a sort of fusion between the genre of chivalric stories (侠义小说, xiayi xiaoshuo) and gong'an stories.

The distribution of these kind of novels during the last decades of the nineteenth century became wider and wider. Full of adventure and combat, they were strongly influenced by novels such as the 水吘传 (Shuihu zhuan, Water Margin) and similar narratives, from which they borrowed the 侠客 (xiake, galant outlaw), a conventional hero of Chinese literature who often rights the wrongs done to the common people and fights aristocrats who abuse their status. ${ }^{9}$ In adventure and detection novels, however, the character of the xiake plays a different role: he serves the official and helps him with the practical work of crime investigation, considering it honourable to do so. The case stories that were written, on the other hand, were mainly borrowed from Ming court-case anthologies, such as 龙图公案 (Long tu gong’an, Cases Judged by Dragon-Design Bao) and 百家 公案 (Baijia gong’an, Cases of A Hundred Families Judged by Dragon-Design Bao), which had the "pure official” Baogong (包公) as protagonist.

Most of these novels were based on oral literature by storytellers, and just later underwent a process of assembling and editing by professional writers or book dealers. This is confirmed by the novels' chaptered structure, the hundreds of characters, the unrefined language in which they were written, and also the emphasis placed on suspense (the so-called 关子 guanzi or 扣子 kouzi), which were typical elements of storytelling

\footnotetext{
7 The early Manchu rulers exercised a heavy ideological control on the literary production, which culminated in the so-called "literary inquisition" (1772-1788) during which thousands of works were destroyed for being considered dangerous to the security of the institutions and to morality. Historians estimate that some 10231 works were placed on the index and 2230 destroyed. See Santangelo e Sabattini (2008), Il pennello di lacca, la narrativa cinese dalla dinastia Ming ai giorni nostri, pp. XXIII-XXIV.

${ }^{8}$ Some examples are the brief crime stories contained in the morality book entitled 雨花香 (Yuhua xiang, Scent of Flower from Heaven) published in 1726 by the literatus Shi Chengjin (石成金, 1660-after 1739). Some information about this work can be found in Hanan (1981), The Chinese Vernacular Story, p. 209.

9 The terms most frequently used to translate xiake are "knight”, "knight-errant”, "swordsman”, or "hero”. These terms are meant to suggest the similarity between the chivalric figures of medieval Europe and the xiake, since both are figures at ease with arms and honourable in their conduct, although the cavalry of the xiake in Chinese fiction must not necessarily coincide with an elevated social extraction or a particular aristocratic lineage. For a comparison between the concept of chivalry in Europe and China, see LIU (1967), The Chinese Knight Errant, pp. 193-208.
} 
narrative. ${ }^{10}$ As a consequence, adventure and detection novels were very different from Ming Dynasty works of fiction, because they presumably displayed the common sense of aesthetic, thinking, and "spirit" of common people during the last years of the Qing governance. ${ }^{11}$

The third genre appears around the mid-nineteenth century. At that time the atmosphere of corruption that permeated the central government and the countryside provoked strong moral anxiety for the state of dynasty and for the spread of its administrative problems to all levels of society. Moreover, during the last two decades of the Qing period, the European influence on literature was beginning to make itself felt throughout China. By this time, at least 170 publishers printed Western detective fiction translated into Chinese, for an audience estimated to be between two to four million readers. ${ }^{12}$ While some writers continued to write long adventure and detection novels which celebrated the figure of the magistrate and the devotion to the regime of the xiake, such as 狄公案 (Digong’an, Cases Judged by Judge Di), other writers deliberately imitated the techniques of Western detective stories, combining them with Chinese crime stories. ${ }^{13}$

Mr. Lu Xun once observed that at the turn of the twentieth century, after over a century of wars, revolts, and invasions by foreign armies which had debilitated the country politically and economically, Chinese people were disappointed with their governance, thus "the trend in fiction was to expose social abuses and lash out at contemporary politics, sometimes at social conventions as well”. ${ }^{14}$ Chinese crime narrative was no exception. While novels of adventure and detection of the previous periods imply celebrate some important officials and gallant outlaws who had been serving under these officials, this submissive and passive attitude was ill-suited to the needs of a population in desire of change. During the last decades of the Qing governance, in fact, novels like Digong'an, while still centered on an idealised government official and celebrating as a consequence the existing regime, could represent one of the most effective methods by which existing politics could be criticised.

\footnotetext{
${ }^{10}$ The first book of its genre to be published is 施公案 (Shi gong'an), whose oldest edition available today is that of 1824 . See MIAO Huaiming (2005), 中国古代公案小说史论 (History of Ancient Chinese Detective Novels, pp. 98-99). The most active publication centres were Beijing and Shanghai, and among publishing houses 务本堂 (The Wuben tang) in Beijing and 上海书 局 (The Shanghai shuju) stand out, but the printing technology was different. While in Beijing more traditional methods were still in use, the publishing houses in Shanghai, from the second half of the nineteenth century, were already benefitting from lithographic printing, which accounts for Shanghai as the major centre of publication in the country. See MIAO (2005), Huaiming (2005), 中国古代公案小说史论 (History of Ancient Chinese Detective Novels, p. 107; FU Xiang-long (2009), 晚明、晚清商业 运作与小说刊印形态之变迁 (On the changes in the publishing business and commercial operations of novels in the late Ming and late Qing), pp. 20-26.

${ }^{11}$ For information on a variety of topics related to gong'an xiayi novels, see also LU Hsun (1976), A Brief History of Chinese Fiction, pp. 336-352; and CAO Yi-bing (2005), 侠义公案小说简史 (A Brief History of Novels of Adventure and Detection).

${ }^{12}$ The famous stories of Sherlock Holmes were the first detective stories that appeared in the Chinese market. The first story was The Final Problem, which was published in 实务报 (Shiwubao) of Liang Qichao in 1894. In 1902 many others appeared as The Adventures of Sherlock Holmes in the section entitled "Translation from English Newspaper". The first complete collection, however, appeared only in 1916. In the 1920s CHENG Xiao-qing (程小青, 1893-1976) wrote a series of novels strongly influenced by Conan Doyle’s Sherlock Holmes series, based on the private detective Huo Sang (霍桑). For further information, see also LIU Wei-min (2011), 侦探小说评析 (Discussion on detective novel), pp. 5-7; Wang Der-wei (1997) Introduction to Fin-de-siècle Splendor: Repressed Modernities of Late Qing Fiction, 1849-1911, pp. 1-3; and WEI Shaochang (1962), 陊荅蝴蝶 派研究资料 (Research on the Mandarin Duck and Butterfly School), pp. 127-130.

13 The novel 九命奇冤 (Jiu Ming Qi Yuan, Nine lives mysteriously wronged) by WU Jian-ren (吴趼人, 1866-1910) is a good example. See Hanan (2005), Chinese Fiction of the Nineteenth and Early Twentieth Centuries: Essays by Patrick Hanan, pp. 162-197.

14 LU Hsun (1976), A Brief History of Chinese Fiction, p. 352.
} 


\section{Digong'an as a Case Study}

狄公案 (Digong’an, Cases Solved by Digong), also titled 武则天四大奇案 (Wu Zetian si da qi'an, Four Great and Strange Cases from the Era of Empress Wu Zetian) is a novel written in 1890. It consists of sixty-four chapters centred around the famous magistrate Digong (狄公, Lord Di, or Judge Di), the fictional counterpart of the Tang Dynasty (618-907) official Di Renjie (狄仁杰, 630-700). The novel takes place during the reign of the Empress Wu Zetian (武则天, 624-705), ${ }^{15}$ and most of the characters are historical figures. In addition to the protagonist, Di Renjie, several other characters are historically documented, such as the government official and painter Yan Liben (阎立本, 600-673), the esteemed official Yuan Xingchong (元行冲, 653-729), Empress Wu, the eccentric abbot Xue Huaiyi (薛怀义, ?-694), the empress’s beloved brothers Zhang Changzong (张昌宗, ?-705) and Zhang Yizhi (张易之, ?-705), etc.

In the Chinese history, Di Renjie was a celebrated official of the Tang regency. He came from a family of bureaucrats and when he was just a boy he began studying Confucian classics and medicine with the help of his father. Around his twenties he finally registered for the imperial examination and passed it successfully. According to historical records, during his office, Di Renjie was credited with solving more than 17,000 legal cases in just one year (675-676). It is said that he displayed extreme caution when investigating a case, avoiding hasty decisions when evidence raised even the slightest doubt about the suspect's guilt. ${ }^{16}$

Di Renjie was an authentic "living legend", and his character in fiction was transformed throughout the centuries according to the needs of authors to entertain, charm, admonish, and warn audiences through literature and drama. As the protagonist of Digong'an, Digong was based principally on the work 狄梁公传 (Di lianggong zhuan), attributed to the Tang famous calligraphist Li Yong (李坙, 678-747), a semi-fictional paradigmatic biography that emphasised the official's good conduct in order to confirm Confucian moral principles; and on the drama in 38 acts of the Ming literatus Jin Huaiyu 金怀玉, titled 狄梁公返周望云忠孝 记 (Di lianggong fanzhou wangyun zhongxiao ji), or simply 忠孝记 (Zhongxiao ji, Records of Loyalty and Filial Piety), in which, as suggested by the title, Di Renjie embodied the perfect model of qingguan 清官, namely the "pure official". Formally, Digong'an was an "old-school" novel at a time when authors were experimenting with "new fiction" inspired by the narrative techniques coming from Japan and Europe. Like the other novels of adventure and detection, two gallant outlaws serves the protagonist, Digong, protecting and aiding him with investigation. Structurally, it still used the paradigm of the chaptered novel, each chapter having a heading of more or less two lines describing briefly the contents. And, like vernacular stories and other traditional oral-related genres in written form, the narrator throughout the novel used stock phrases of introduction, connection, and conclusion, and introduced the main narrative with a poem in the vernacular. The story of Digong'an is about six criminal cases connected with the typical techniques of vernacular tradition, while the most common technique is to interrupt a criminal investigation and begin another investigation, delaying the solution of each case and engaging the reader's curiosity. ${ }^{17}$

\footnotetext{
15 The biography of Wu Zetian is found in 旧唐书 (Jiu Tangshu, Old Tang Book)—compiled by LIU Xu 刘昫 (888-947), politician and writer of the late Jin from 940 to 945 . For a semi-fictional biography largely based on historical documents of Empress Wu, see the famous book Lady Wu: A True Story (1957), written in English by Lin Yutang (林语堂, 1895-1976).

${ }^{16}$ The literature on Di Renjie, popularly referred to as Digong, is not so voluminous. His biography is found in juan 89 of the Jiu Tangshu. For a contemporary study, see also DU Wen-yu (2000), 狄仁杰评传 (Commented biography of Di Renjie).

${ }^{17}$ On the narrative models of gong'an vernacular stories and novels, see also DING Can, \& HU He-ping (2007), “我国公案小说 叙述模式探析 (On the narrative modes of Chinese detective stories), pp. 91-93.
} 
The Dutch sinologist Robert Hans van Gulik (1910-1967), who translated thirty chapters of the novel, noticed that the novel seemed to be composed of two different parts of approximately thirty chapters, which are clearly set apart from each other in both style and content. ${ }^{18}$ He opined that the first part of the novel was a complete story itself, while the second part was a later addition. In terms of content, his theory effectively would make sense, since the two parts are very different: while murder cases recounted in the first part focus on the magistrate's investigation of ordinary criminal cases, after chapter thirty Digong is engaged in political cases, fighting corruption and dishonesty. Thus, each part embraces a different type of crime and criminal. In the first thirty chapters, Digong with the help of his assistants investigates three murder cases that involve ordinary members of the local communities. ${ }^{19}$ The next thirty-four chapters concern three criminal cases as well, though they are all related to abuse of power and corruption by politicians and bureaucrats during office. While in the first part historical events take place off-stage and the fictional characters simply inhabit the world where those events happen, in the second part historical events play a role in the narrative, and the majority of the characters are fictional versions of historical figures.

In terms of structure, a scene that occurs in Chapter thirty-one connects the two parts: Digong is promoted to high-level imperial officer and called to the capital. On the way to his new office, he accidentally overhears a few men complaining about the behaviour of a local magistrate who commits abuse of power. This technique of connecting cases was also typical of vernacular narrative. Here is a translation of part of the passage.

Digong had just arrived in the prefecture. He was carrying out his personal investigations, when suddenly, over in a local village, he saw many people surrounding an old man in his fifties passionately arguing. Almost unconsciously he and Ma Rong approached the crowd, hearing a man say: "You do not know how terrible he is; last month Wang Xiaosan's son, because of what happened to his wife, was nearly beaten to death!” (Digong'an, 2009, p. 180) ${ }^{20}$

That is how the second part begins. Digong starts to look for clues to determine whether or not such crimes have taken place, and finds out that the criminals are all related to members of the ruling class very close to Empress Wu commit abuse of power. Without hesitation, Digong tries them as if they were ordinary people. While the first part of the novel demonstrates that he was a very talented man, capable in investigating criminal cases, here Digong has the occasion also to prove himself as honest, incorruptible, and virtuous-as a pure official would be. The last thirty chapters are therefore dedicated to combating the damaging effects of corruption in the administration.

Digong's overturning of unjust verdicts and his battle against corruption actually gives readers more confidence in the system by demonstrating its effectiveness even in the most extreme cases. However, the first thing that catches the readers' eye is the leeway given to administrative malpractice and the fact that most of the political representatives seems to be corrupted and depraved. The reader realizes that politicians are too corrupted and a change of mentality is very much needed. Thus, the novel highlights the need for a "new" outlook, conceived as based on the revival (and reinterpretation) of traditional Confucian values. The fact, therefore, that the two parts of the novel may have been extracted from different narrative material and just then

${ }^{18}$ Van Gulik (Ed.) (1976), Celebrated Cases of Judge Dee. (Dee Goong An) An Authentic Eighteenth-century Chinese Detective Novel, p. 225.

${ }^{19}$ This section has been adapted into English by van Gulik who, likewise, attributed a name to each criminal case: The Double Murder At Dawn, The Strange Corpse and The Poisoned Bride. For a discussion about van Gulik's translation, see Benedetti (2014), “Killing Digong: Rethinking van Gulik’s Translation of Late Qing Dynasty Novel Wu Zetian si da qi'an”, pp. 11-42.

${ }^{20}$ Unless indicated otherwise, all translations are made by the author of this article. 
assembled into a single novel seems to be unimportant, because the two parts result as two indispensable components to serve the assembler's idea on politics: the Country does need a change, but without the support of traditional values - to develop the rulers' moral integrity, sense of justice and social responsibility, compassion and benevolence- the crisis would become even worse.

\section{The Anonymous Author}

At this point a reflection on the identity of the author is needed. The oldest edition brought down to us of Digong'an is a lithographic printing published by Shanghai shuju 上海书局 in 1890. By that time Shanghai was the hub of all publishing activities in China, and a lot of adventure and detection novels were rashly being published to meet the public demand for more and more stories. In this period, many men of letters were collaborating with bookshops, and booksellers themselves personally took on assembling books to meet the huge demand of readers more rapidly.

At the very beginning of Digong'an, the author introduces the case stories with a long introduction, partly in prose and partly in verse, in which he declares not to be the writer of the story that follows, but only to have copied it from a manuscript. Is this man a literatus?

Why did he decide to copy certain texts over others?

The wind of spring encourages indolence, the days pass without having done anything, for this reason I prepared to copy the original volume of this book, in order to offer it to the entire population. I dare not say that it will edify and ennoble character, but it may nonetheless alleviate the solitude of those who read it. (Digong'an, 2009, p. 2)

Some scholars hypothesised that this man might be a man from the South. ${ }^{21}$ Such was proved by the fact that within the text he uses terms that belong to the dialects of the Southern provinces, and that he seems unfamiliar with the geography of the Northern region. Just an example: he refers to the district of Changping as if it belongs to Shandong province, but Changping, neither in the Qing era (the era in which the author lived) nor in the Tang period (the time period of the novel), never belonged to Shandong province.

Beyond geographical mistakes, the narrative is set in a historical past duly described, ${ }^{22}$ although the criminal cases are fictional and maybe copied from previous narrative material. Nonetheless, there are frequent historical inaccuracies within the text. Some examples: first, Digong, takes office as the local magistrate of Changping, yet according to the historical documents, at the beginning of his career he held the office in the district of Pengze.

Second, in Chapter thirty one, the author confuses the capital of the Tang Dynasty with the capital of the Song Dynasty:

Ever since the Tang dynasty came to power after the Jin and Sui, they have moved the capital to Bianliang, a strategic area of the Henan province. (Digong'an, 2009, p. 179)

Third, the author also confuses the names of offices. One of the antagonists, called Zhou Bucheng (周卜 成), is sometimes designated as 县令 (xianling) and sometimes as 知县 (zhixian). We know that county

\footnotetext{
${ }^{21}$ DU Wen-yu (2000), 狄仁杰评传 (Commented biography of Di Renjie), pp. 283-317.

${ }^{22}$ Ma Yau-Woon observes that after the publication of 仰斋志异 (Liaozhai zhiyi, Strange Tales of Liaozhai) by Pu Songling (蒲 松龄, 1640-1715), which included also numerous stories of legal cases, the authors of fiction stories tended to refer to concrete events and individual historical figures in a more precise way. See Ma Yau-Woon (1979), "Kung-an Fiction: A Historical and Critical Introduction”, pp. 235-240.
} 
magistrates in the Tang Dynasty were called xianling, and just in the Ming Dynasty (1368-1644) and in the Qing Dynasty (1644-1911) they were called zhixian. ${ }^{23}$

Fourth, Digong is appointed as 巡抚 (xunfu, provincial governor), while this title was only used in the Ming and Qing periods. ${ }^{24}$

Empress Wu, though dissolute and tyrannical, knew well that only a man of extraordinary talent and celebrated virtue could supervise the area around the capital, and for this reason she nominated Di Renjie as xunfu of Henan. (Digong'an, 2009, p. 179)

Fifth, in Chapter fifty-seven, a character called 安金藏 (An Jincang, dates unknown) in the novel has an official post, while in the reality he had none. ${ }^{25}$

An Jincang was employed of the Temple of Taichang. Being a low functionary, all that he had heard was that the prince had suffered an injustice and had been punished with death. (Digong'an, 2009, p. 357)

An Jincang in fact refers to himself as "chen" (臣), the form of reference to oneself used by an officer when speaking to superiors.

Chen An Jincang will rectify the injustice committed towards the crown prince, and if her majesty continues to not believe me, I fear that Jiangshan will lose a traitor. (Digong'an, 2009, p. 357) ${ }^{26}$

Sixth, in Chapter twenty-eight a woman is sentenced to 凌迟 (lingchi, slow death) for murdering her husband, and we know that this method of death execution was very common during the Qing era but we do not have any information about this method in the Tang Dynasty. ${ }^{27}$

In my opinion, the abovementioned historical and geographical inaccuracies (there are many others) do not prove that the author was not a member of literati. His emphasis on Confucian moral principles is all too palpable throughout the novel. Furthermore, even if he uses a very simple language, this is probably meant as a way to reach and instruct all kinds of readers, which strengthens the hypothesis of his being a man of letters. Below there is an extract from his long introduction:

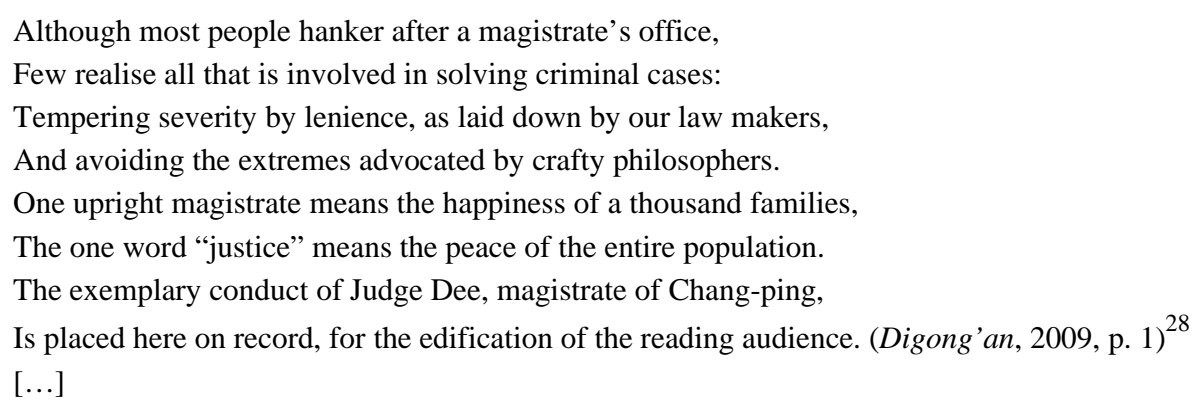

${ }^{23}$ See YANG Zhong (2003), Local Government and Politics in China, pp. 18-19.

${ }^{24}$ For further information about the official titles in Imperial China, see Hucker, 1985, p. 255.

${ }^{25}$ Brief references to An Jincang may be traced in scrolls 205 and 213 of the Comprehensive Mirror to Aid in Government (Zizhi tongjian, 资治通鉴), a vast chronology of the general history of China in 294 scrolls written by Sima Guang (司马光, 1019-1089) and his collaborators and published in 1084. The book covers the 403-959 period.

${ }^{26}$ Here An Jincang is threatening to kill himself.

${ }^{27}$ For more about the origin of the Chinese form execution known as lingchi, see Brook, Bourgon, \& Blue (2008), Death by a Thousand Cuts, pp. 68-121.

${ }^{28}$ Partly based on Van Gulik’s translation. See Van Gulik (Ed.) (1976), Celebrated Cases of Judge Dee. (Dee Goong An) An Authentic Eighteenth-century Chinese Detective Novel, p. 5. 
From the time that adulterers, thieves, the wicked, and the lascivious came to exist, no one has managed to escape from the imperial laws, but it is the task of the magistrate to decide whether these have been just accused justly or not. If the magistrate is honest, the people are at peace, and if the people are at peace, their morality remains intact. (Digong'an, 2009, p. 1)

Nevertheless, the historical and geographical mistakes do demonstrate that the novel was the result of an assembling process that included different pre-existing texts. One of the texts that influenced Di gong'an could be 三侠五义 (Sanxia wuyi, Three Heroes and Five Gallants), a very popular novel of adventure and detection which recounts case stories solved by judge Bao, most of which originated in Longtu gong'an. ${ }^{29}$ The author of Digong'an, in fact, often switches to the Song Dynasty, that is the era in which Three Heroes and Five Gallants is set. On the other hand, we should not underestimate the fact that the author more often than not switches to Qing Dynasty. This "mistake" was probably done on purpose, and it is maybe due to the fact that the author wanted to turn readers' attention to the contemporary era.

\section{The Political Criticism of Digong'an}

If we divide the text in two different parts, ${ }^{30}$ we can easily notice that while the three cases recounted in the first part are structurally and thematically more similar to Ming-style collections of short court-case stories, such as those included in the aforementioned Longtu gong'an, the second part seems to have been influenced by Ming period erotic fiction, as for example the novel 如意君传 (Ruyijun zhuan, The Biography of Lord Perfect Satisfaction), ${ }^{31}$ which centres around Empress Wu Zetian's extravagant love affairs and around her pursuit of an ideal sexual partner.

Nevertheless, if one reads the two parts closely, one will find that these two are in some way interrelated, as they highlight social problems at different levels of society. The first part highlights the question of the moral depravity of the people, showing the social situation of a district far from the capital, where there is a concentration of crime. Digong solves all the crimes and the district is finally at peace, implying the idea that the wellbeing of the people actually depends on the morality of every single "small" official. The second part, on the contrary, means to shed light on the government corruption deeply rooted in the imperial system, blaming it on the lack of good institutional models. Moreover, as a whole, the novel would represent two different phases of Di Renjie's career. His biography, in fact, tell us that in 675 Di Renjie was promoted to officialdom in central government levels since he was believed to be very capable.

But the most important element of interaction between the two parts seems to be that in each part there is a negative representation of a woman that stands out from the stories: the adulteress and murderer Mrs. Zhou in the first part, and the depraved Empress Wu Zetian in the second part.

\footnotetext{
${ }^{29}$ First published in 1879 under the title 忠烈侠义传 (Zhonglie xiayi zhuan), Sanxia wuyi is traditionally attributed to the famous storyteller Shi Yukun whose performance in retelling the legends of Baogong, accompanied by musical instruments, gained exceptional fame all over the Country and attracted audiences of thousands. However, in 1879, Shi Yukun probably had already passed away; some scholars assumed that the core story of Sanxia wuyi could be based on his promptbooks used by him when he performed, and that it underwent a process of rewriting and assembling by many different hands. Extensive literature closely references the Sanxia wuyi. Some important texts are: Sun Kaidi (1985) 包公案与包公案故事 (Judge Bao and Judge Bao stories); Hu Shi' s introduction to Sanxia wuyi, Hu Shi (1988), 胡适古典文学研究论集 (Hu Shi' s Classical Literature Essays), p. 1174 and the following; see also Lu Hsun (1976), A Brief History of Chinese Fiction, pp. 336-352.

${ }^{30}$ See Van Gulik (Ed.) (1976), Celebrated Cases of Judge Dee. (Dee Goong An) An Authentic Eighteenth-century Chinese Detective Novel, p. 225

${ }^{31}$ For a study and a partial translation in English of the Ruyijun Zhuan, see Stone (2003), The Fountainhead of Chinese Erotica, The Lord of Perfect Satisfaction (Ruyijun zhuan).
} 
Mrs. Zhou is the murderer of the longest crime story in the first part of the novel. She appears in Chapter four. She is accused of the murder of her husband, who died suddenly in a mysterious way on the night of the Dragon Boat Festival. Digong learns of the fact almost by chance. Disguised as a doctor, he was collecting evidence to investigate a crime when he met an old woman, who lost her son in unclear circumstances. Desperate and poor, the woman confides to the doctor (the disguised magistrate) her unfortunate story, and it immediately stimulates his curiosity. Determined to examine the matter more deeply, Digong finds a pretext to go to the woman's place, but as soon as he enters in the house, he is informed that she lives with her daughter-in-law (Mrs. Zhou), who is easily angered:

At my house there is only my daughter-in-law and me. During the day we are together, but in the evening each of us returns to own room. If you come to our home sir, you may prepare the medicine in the central room, but once it is ready, I ask that you leave swiftly to avoid that she gets angry at me again. (Digong'an, 2009, p. 20)

This warning increases suspicions of Digong who, upon entering the house, tries by every mean to meet the daughter-in-law. When the magistrate is finally able to peek inside the room, it only takes him one glance to understand that the woman is responsible for the death of her husband.

Judge Di peeked out from the room and caught a glimpse of the daughter-in-law. She was a woman under thirty years of age, wearing no make-up and dressed in a simple manner, but even so one could succeed in perceiving the voluptuousness of her eyes and the radiance of her person. She was so beautiful that one could lose their soul. Her eyebrows slightly curved, her face white as snow, with a timid blush on her cheeks [...] After seeing her expression, Judge Di understood: "this woman must not be a good person. Certainly there is something hidden beneath this facade". (Digong'an, 2009, p. 21) ${ }^{32}$

The narrator describes Mrs. Zhou in a totally negative way through a number of devices. First of all she is a very seductive woman, and that is enough to arise the idea she is evil in magistrate's mind. She is too charming to be a good wife and a grieving widow, and her attractiveness proves to the official that she murdered her spouse. ${ }^{33}$ She is in fact an adulteress, and this inexcusable act against society could not help but run into extremely retributory measures.

Convinced of the involvement of Mrs. Zhou in the death of her husband, Di Renjie begins an investigation that will sniff out the existence of a young lover. The young man is portrayed as a naive victim, who falls into the trap of the older woman's seduction. His guiltiness is even considered "understandable", because any man may happen to be incapable of resisting the wiles of a beautiful woman. Once Mrs. Zhou traps her "prey", she reveals her bad intentions. She decides on her own accord to murder her husband, getting also her young lover in serious trouble and he, at the end of the case-story, even will lose his life for it. Even if he is guilty only of ingenuousness, he cannot help but suffer the retribution for his bad acts. Digong starts a lengthy investigation, and encounters many obstacles to solve the case, because he is not able to understand how the skilled woman killed her husband without leaving any trace of the corpse. When he finally identifies the criminals, he brings both lovers to court. While the young lover confesses immediately, Mrs. Zhou is determined in not admitting her crime. The magistrate is obligated to use various instruments of torture to extort a confession, but she resists

\footnotetext{
32 The adaptation of into English by van Gulik is slightly different; cfr. Van Gulik (Ed.) (1976), Celebrated Cases of Judge Dee. (Dee Goong An) An Authentic Eighteenth-century Chinese Detective Novel, pp. 35-36.

${ }_{33}$ In the Chinese penal code, the killing of the husband by his wife was considered one of the most serious homicides, see T’ung-tsu Ch'ü, (1969), pp. 119-124.
} 
every type of physical torture. ${ }^{34}$

At the second occasion, Digong speaks to her in a very harsh and offensive way from the start, using phrases such as “you, lascivious woman”, or "you, ignoble and depraved woman”. Besides this, she is humiliated, tortured, stripped, and insulted, such as in the court scene described below:

When he finished his speech, Judge Di ordered that she be put again into the press: she was immobilised on the ground, while both her legs were placed through the holes. As soon as the cord was tight and the stick inserted, a howl of pain was heard, before her eyes turned back in her head and she lost consciousness [...] Judge Di, having witnessed the behaviour of Xu Detai, understood that he had not acted under his own free will, and so ordered that the bonds of Mrs. Zhou be loosened and that fresh water be sprinkled on her face. After some effort, the woman succeeded in regaining consciousness, stretched out in the pool of fresh blood that flowed from her legs and covered her feet. (Digong'an, 2009, pp. 159-160)

Mrs. Zhou is very quick-tempered and replies in a disrespectful tone, addressing the magistrate with phrases such as “you, dog of a magistrate”. In this way she demonstrates to have no respect for authority. She also uses offensive language towards her mother-in-law, who represents the head of the family, since there are no other men in the house. Being a married woman and a member of her husband's lineage, first of all she should show deference towards her mother-in-law in accordance to the cultural imperatives of filial piety. In a strictly structured society, as according to the Confucian world view where human relationships are hierarchical in nature and respect is a necessary value to maintain fundamental relationships, Mrs. Zhou's rude language is particularly shameful. Confucian morality established “three submissions” (三从, sancong) to guide and direct women's behavior to provide order in social relationships. They compel a woman to "obey her father reverently before marriage” (未嫁从父, weijia cong fu), “to serve the husband diligently after marriage” (既嫁从夫, jijia cong fu), and lastly, “to listen to male son during widowhood” (夫死从子, fu si cong zi). Obedience and filial piety are considered fundamental civic duties of a "good woman”, and Mrs. Zhou surely did not conform to social roles and norms.

For these reasons she is humiliated also in death. After having been sentenced to lingering death, her head is exposed on the city gate. This measure does not only serve as a deterrent to people criminal behaviour, but the disemboweled body also symbolises Mrs. Zhou's lack of filial piety. Preserving the integrity of the body in fact is also a form of filial piety, as Confucian teachings maintain that the body and skin coming from our parents should not be damaged.

Like Mrs. Zhou in the first part of the novel, the negative figure of Empress Wu Zetian stands out from the second part, which is dedicated to criminal cases that are the result of Empress' bad regency. Her scandalous affairs are not a new topic in Chinese literature. Both official historiography and popular literature represented her as an oversexed and vicious female tyrant, and accused her having destabilised the Tang's administration system, to have usurped her husband and her son's power, to have maintain extravagant love affairs with young men, and to have put them in the position to damage the people etc. ${ }^{35}$ This negative judgment of the Empress is

\footnotetext{
${ }^{34}$ According to Chinese law, the magistrate needed to obtain a guilty confession by the end of the interrogation, and if he were not to get it, he was legitimized to use various implements on the accused, like bamboo sticks or special contraptions to bend fingers. In Qing period, however, the use of physical and psychological torture, although frequent during trials, was to be strictly regulated according to the penal code of the various dynasties. This problem was much discussed during the Qing Dynasty and regulated by 大清律例 (Da-Qing lüli, The Qing Code). See Brook, Bourgon, and Blue (2008), pp. 35-68.

${ }_{35}$ On this topic see Dora Shu-fang Dien (2003), Empress Wu Zetian in Fiction and in History: Female Defiance in Confucian China.
} 
more than just political. She was in fact an unprecedented case in Chinese history: not only she occupied the position endowed to a man, but she even crowned herself "emperor". In this way she disturbed the Confucian framework of positional and proportional relationships and inverted the cosmological yin-yang order, although the yin-yang logic applied to the Confucian view of society actually should not imply male supremacy.

But more than just that, the author insists on shedding a light on the Empress's bad administration and on the negative impact of it on the life of people. Many times in the novel the narrator complains about Wu Zetian as a sovereign who, as soon as she came to power, brought society to a condition of maximal disorder:

This book is about the reign of Emperor Zhongzong, when Empress Wu rose to the throne and there was confusion in every place. (Digong'an, 2009, p. 2)

She is depicted as a ruler who has completely disregarded the traditions represented by the sage-kings, because she did not manage to preserve order by giving the good example. Since people should rely on authorities' sense of what is right and emulate their behaviour, Wu Zetian was a bad example that led people to do likewise. Confucius himself said: "If you set an example by being correct, who would dare to remain incorrect?” (The Analects, XII: 17). This idea is exposed all throughout the novel, as shown in the passage below:

From the time that Empress Wu usurped the throne, ignorant and incapable men have risen to power, they destroyed good and honest men, killed sisters and brothers, assassinated gentlemen and mothers. Here are exposed many bizarre cases, all that have been solved by Judge Di. (Digong'an, 2009, p. 3)

From that moment forward [Wu Zetian's] wicked deeds increased: she killed Empress Wang and the concubine Xiao, then took the place of empress in the palace. From that moment on began her dissolute and tyrannical reign, which brought confusion and obscenity to the palace. After the death of Gaozong, she even exiled the son of Heaven Zhongzong, ${ }^{36}$ who was reduced to the title of Prince of Luling. (Digong'an, 2009, p. 172)

The author's disdain for the Empress's administration is expressed also by putting scornful references to her and her closest collaborators in the mouths of positive characters that serve as mentor figures in the narrative. The governor Yan Liben, a good officer that was the first to recognise the value of Digong, for example, often expresses his opposition towards the Empress by complaining about her conduct, such as:

Now that Empress Wu has ascended the throne, there is confusion and obscenity at court, but you cannot say so! (Digong'an, 2009, p. 178)

In Chapter thirty-two, the confidant and friend of Digong, Yuan Xingchong, manifests his worry over the breakdown of morality at court.

Who would ever have imagined that just in a few years the emperor would die and the empress would ascend the throne? State affairs are no longer the same, corruption grows each day and the greater part of the experiences and expectations of the preceding emperor have vanished. (Digong'an, 2009, p. 187)

The dissent towards Empress Wu also emerges indirectly through the negative characterisations of those characters in her confidence. The three episodes of abuse of authority are all caused by the immoral behaviours of exponents of the ruling class. These men have succeeded in obtaining prestigious positions thanks to their

\footnotetext{
${ }^{36}$ Emperor Zhongzong (中宗, 656-710) was the son of Emperor Gaozong and Empress Wu. He succeeded his father in 684, but Wu Zetian deposed him in less than two months in favour of his younger brother Emperor Ruizong (睿宗, 662-716). As in the novel, he was demoted to a princely rank, sent into exile in the provinces, and put under house arrest.
} 
relationship with Wu Zetian, whether through family or affective ties. They are the so-called nanchong (男宠), who enjoy the absolute protection of the Empress, including her two ambitious nephews Wu Sansi (武三 思, ?-707) and Wu Chengsi (武承嗣, 649-698), the ambiguous Xue Huaiyi, and the Empress's young lovers Zhang Changzong and Zhang Yizhi. ${ }^{37}$ Within the novel these immoral political figures create an authentic clique of power, which strengthens itself by giving each other consistent solidarity, abusing their status, and committing ignoble acts against ordinary people. The people have no way to defend themselves, because the representatives of the legal profession belong to this very caste.

One example of abuse of power is the case of the abduction of the beautiful Miss Wu. The daughter-in-law of an honest man, Hao Ganting, is kidnapped by the influential Ceng Youcai, son of a servant of Zhang Changzong. Hao Ganting denounced the kidnapping to the yamen, but the local magistrate did not pursue the kidnapper since they were good friends. Digong solves the case and finds the kidnapper. After that Digong has no scruples in imprisoning and using physical force on those responsible for the heinous crime, making enemies amongst very influential people. And he goes further. He insults them repeatedly by using phrases such as "Wu Sansi, you dog head" (Digong'an, 2009, p. 287), permitting even his lieutenants to not hold much respect towards them. When his assistant Ma Rong meets Xue Aocao (薛敖曹), one of the lovers of the empress, ${ }^{38}$ for example, he first bumps into him voluntarily and then addresses him with the rude words: "You, dog head, why don't you use your eyes—it's as if you were blind!” (Digong'an, 2009, p. 308).

\section{Conclusion}

This paper unlighted that both female characters of Digong'an are the symbolical personifications of social and political disorder. In both cases the author emphasised the importance of womanly virtue for maintaining social and cosmological order by illustrating the ill effects of such opposing behaviour on society. We should argue that one way of understanding the author's criticism of women is to attribute it to the prevailing sexism implied by the Confucian idea of a rightly ordered society, in which the woman's role has to be relegated to indirect social and political participation by supporting her husband and son. However, the author recognises female cleverness and puts a degree of emphasis on women's mental capabilities. Mrs. Zhou and Empress Wu are both sly enough to test the judge's capability: the "feminine” machinations of Mrs. Zhou challenge Digong's intelligence and represent obstacles that he must overcome with wisdom. The empress is also very skilful, although she is capable of choosing her officials but not to maintain order, as it is shown in passages like the one below:

Empress Wu, though dissolute and tyrannical, knew well that only a man of extraordinary talent and celebrated for his virtue could supervise the area around the capital, and for this reason she nominated Di Renjie as governor of Henan. (Digong'an, 2009, p. 179)

\footnotetext{
${ }^{37}$ As recorded in the Old Tang Book, Empress Wu brought to the palace a few of her favourite young men to wait on her every need. Her first “favourite” was Xue Huaiyi. Xue Huaiyi was originally a businessman named Feng Xiaobao (冯小宝), but the empress changed his name into Xue when he turned into a monk, appointing him as head monk of the Temple of the White Horse in 685. As many narrative works recount, Wu Zetian had an affair with Xue Huaiyi, but was dissatisfied with his sexual performance and his rude manners, which is why she searched for other lovers. This is how the young brothers Zhang Changzong and Zhang Yizhi were introduced to Empress Wu; they soon became her favourites and were granted with official positions. See for example Woo (2008), Empress Wu the Great: Tang Dynasty China, pp. 151-159.

${ }^{38}$ This character also appears in the most famous Ming erotic fictions on Empress Wu, The Biography of Lord Complete Satisfaction (Ruyijun zhuan), where Xue Aocao is a man with an unusually large penis who loyally serves the empress's sexual needs, and paradoxically, he is also a virtuous Confucianist that is very frustrated because he is only valued for his sexual performance.
} 
Even if women can be skilful enough, the author's main concern is to illustrate the undesirable effects that spark from their participation in political life, and entirely devotes the second part of the novel to illustrate said destructive influence on state governance.

At the end of the nineteenth century, the author's negative view of female participation in politics cannot be attributed just to his conservative Confucian ideas. His criticism can be attributed to a specific woman who, at the time, ruled the empire even if she had not been formally legitimised: the Empress Dowager Cixi (慈禧, 1835-1908). Both female figures represented in the novel recall the figure of the Empress Dowager. The beautiful and irreverent Mrs. Zhou is a determined woman who, in order to reach her objective, does not hesitate to poison her little daughter by making her drink a potion that will leave her mute. This episode can be interpreted as an allusion to the fact that Cixi presided over government decisions "from behind the curtain" in the place of two emperors, ${ }^{39}$ metaphorically putting a gag on the legitimate rulers.

The representation of Empress Wu Zetian is also easily associated with the figure of Cixi. They undoubtedly shared a similar political course: both entered the palace as concubines and both occupied a position originally assigned to a man. Moreover, during the last years of the Qing regency, it was quite common to associate the name of Wu Zetian with that of Cixi, drawing a comparison between Cixi's reclaiming the regency over Guangxu (光绪, 1871-1908) and Wu Zetian's dethroning her son, the future Emperor Zhongzong. The polemical novel (also by an anonymous author) entitled Wu Zetian, which A Ying (阿英) cites in his catalogue of novels of the late Qing period, the 晚清小说目 (Wanqing Xiaoshuomu), for example, used the same comparison. And also many years later, in the 1930s, the follower and great admirer of Kang Youwei (康有为, 1858-1927), Zhang Bozhen (张伯桢, 1877-1946), in his 南海康先生传 (Nanhai Kang xiansheng zhuan, the biography of Mr. Kang of Nanhai), wrote:

[Kang Youwei] wrote a request for help, speaking of the situation in the country, denouncing the ten greatest crimes committed by the Empress. He told about the Emperor and his falling into the clutches of the Feiyan ${ }^{40}$ and the disastrous clan of Zetian. ${ }^{41}$

We should therefore conclude that the author's misogyny stems, primarily, from one of the most traditional Confucian concepts, which claimed that the political activity of women was disruptive. On the other hand, however, the novel seems to be far less conservative than it looks. The author does not spend too many words celebrating Confucian orthodoxy; on the contrary, he seems to promote a way to restore and reinterpret Confucian morality in order to better address the difficulties of China at the time. That itself represents a departure from conservatism and a small step towards radical change of mentality.

\section{References}

A, Ying. (1980). 晚清小说史 (History of late Qing fiction). Beijing: 北京人民出版社.

Alford, W. P. (1984). Of arsenic and old Laws: Looking a new at criminal justice in late imperial China. California Law Review, 72(6/2), 1180-1256.

Altenburger, R. (2009). Early Qing Yangzhou in Shi Chengjin’s vernacular vignettes. In L. Olivovà and V. Børdhal (Eds.),

\footnotetext{
${ }^{39}$ Cixi ruled de facto from 1861 to 1872 in the place of her son Emperor Tongzhi (1856-1875) and from 1875 to 1889 in the place of his nephew Emperor Guangxu 光绪 (1871-1908).

${ }^{40}$ Zhao Feiyan (赵飞燕, c. 32-31 BC), or Empress Xiaocheng (孝成皇后), was the wife of Emperor Cheng (成帝, 51-57 BC) during the Han dynasty. She is known in popular culture for her exceptional beauty, and has been often vilified by historians and novelists. She is frequently associated with Yang Guifei (杨贵妃, 719-756), Wu Zetian, and Cixi.

${ }^{41}$ SU Xing (2006). 武则天四大奇案散论 (Essay on Wu Zetian si da qi'an), p. 41.
} 
Lifestyle and entertainment in Yangzhou (pp. 147-173). Copenhagen: NIAS Press.

Backus Rankin, M. (1982). "Public opinion” and political power: Qingyi in late nineteenth century China. The Journal of Asian Studies, 41(3), 453-484.

Bauer, W. (1974). The tradition of the “Criminal Cases of Master Pao” Pao-kung-an (Lung-t’u kung-an). Oriens, 433-449.

Benedetti, L. (2013). Justice and morality in Early Qing crime fiction. In P. Santangelo (Ed.), Ming Qing studies 2013 (pp. 17-46). Roma: Aracne.

Benedetti, L. (2014). Killing Digong: Rethinking van Gulik’s translation of late Qing Dynasty novel Wu Zetian Si Da Qi'an. In P. Santangelo (Ed.), Ming Qing studies 2014 (pp. 11-42). Roma: Aracne.

Blader, S. (1998). Tales of Magistrate Bao and his valiant lieutenants. Hong Kong: The Chinese University Press.

Brook, T., Bourgon, J., \& Blue, G. (2008). Death by a thousand cuts. Cambridge: Harvard University Press.

CAO, Y. B. (2005). 侠义公案小说简史 (A brief history of novels of adventure and detection). Taiyuan: 陕西人民出版社.

Ch'ü, T. T. (1988). Local government in China under the Ch'ing. Cambridge: Harvard University.

CHANG, W. J. (2009). Classical Chinese jurisprudence and the development of the Chinese legal system. Tsinghua China Law Review, 2, 207-272.

CHENG, R. F. (2009). 包公传 (Biography of lord Bao). Hefei: 黃山书社.

Collotti Pischel, E. (1982). Storia della rivoluzione cinese (History of Chinese revolutions). Roma: Editori Riuniti.

Dien, D. S. F. (2003). Empress Wu Zetian in fiction and in history: Female defiance in Confucian China. New York: Nova Science Publishers.

Digong'an. (2009). Zhengzhou: 中州古籍出版社.

DING, C., \& HU, H. P. (2007). 我国公案小说叙述模式探析 (On the narrative modes of Chinese detective stories). Journal of Hunan Public Security College, 6, 91-93.

DING, Z. Q. (2000). 俗文学中的包公 (Baogong in vernacular literature). Taipei: 文津出版社.

DU, W. Y. (2000). 狄仁杰评传 (Commented biography of Di Renjie). Xi’an: 三秦出版社.

FU, X. L. (2009). 晚明、晚清商业运作与小说刊印形态之变迁一一以晚明建阳书坊和晚清上海书局为中心 (The changes in trade and pubblication from Late Ming to Late Qing). 中国文学研究, 4, 20-26.

Yu-Lan, F. (1990). Storia della filosofia cinese (History of Chinese philosophy). Milano: Mondadori.

Hanan, P. (2005). Chinese fiction of the nineteenth and early twentieth centuries: Essays (Vol. 2). New York: Columbia University Press.

Hanan, P. (1981). The Chinese vernacular story (No. 94). Cambridge: Harvard University Press.

Hegel, R. E., \& Carlitz, K. (Eds.). (2007). Writing and law in late imperial China: Crime, conflict, and judgment (Vol. 18). Seoul: Ewha Womans University Press.

HU, S. (1988). 胡适古典文学研究论集 (Collection of Hu Shi’s essays on classical literature). Shanghai: 上海古籍出版社. HUANG, Y. B. (2000). 公案小说史话 (History of crime fiction). Shenyang: 辽宁教育出版社.

Hucker, C. O. (1985). A dictionary of official titles in imperial China. Redwood City, California: Stanford University Press.

Ko, D., Haboush, J. K., \& Piggott, J. R. (Eds.). (2003). Women and Confucian cultures in premodern China, Korea, and Japan. Oakland: University of California Press.

LI, S. X. (2006). 侠义小说和公案小说合流的社会文化探源 (Social and cultural roots causes of confluence of chivalry stories and crime stories). Journal of South-Central for Nationalities, 26(1), 160-162.

Rosenlee, L. H. L. (2012). Confucianism and women: A philosophical interpretation. New York: SUNY Press.

LIN, Y. (1957). Lady Wu: A true story. Mumbai: Jaico Publishing House.

LIU, J. Y. (1967). The Chinese knight errant. London: Routledge and Kegan Paul.

LIU, X. (1924). 归唐书 (The old book of Tang). Beijing: 中华书局.

LIU, W. M. (2011). 侦探小说评析. Nanjing: 东南大学出版社.

LU, H. (1976). A brief history of Chinese fiction. Beijing: Foreign Language.

Ma, Y. W. (1979). Kung-an fiction: A historical and critical introduction. T'oung Pao, 200-259.

MIAO, H. M. (2005). 中国古代公案小说史论 (History of ancient Chinese crime novels). Nanjing: Nanjing University.

Sabattini, M., \& Santangelo, P. (Ed.). (2006). Storia della Cina (History of China). Bari-Roma: Laterza.

Santangelo, P. (2008). Il pennello di lacca, la narrativa cinese dalla dinastia Ming ai giorni nostri (The Lacquer Brush: the 
Chinese Narrative from the Ming Dynasty to the Present Day). Bari: Editori Laterza.

Stone, C. R. (2003). The Fountainhead of Chinese erotica. The lord of perfect satisfaction. Honolulu: University of Hawai'I Press.

SU, X. (2006). 武则天四大奇案散论 (Essay on Wu Zetian si da qi'an). Journal of Dalian University, 27(1), 39-41.

Van Gulik, R. H. (1976). Celebrated cases of Judge Dee: An authentic eighteenth-century Chinese detective novel. Mineola-New York: Courier Corporation.

Wang, D. W. D. (1997). Introduction to fin-de-siècle splendor: Repressed modernities of late Qing fiction, 1849-1911. Stanford: Stanford University Press.

Wei, S. C. (1966). 然奇蝴蝶派研究资料 (Research on the Mandarin Duck and Butterfly School) (2 Vols.). Shanghai: 上海文 艺出版社.

Woo, X. L. (2008). Empress Wu the great: Tang Dynasty China. New York: Algora Publishing.

YANG, Z. (2003). Local government and politics in China: Challenges from below. New York: ME Sharpe. 